Persp. Teol. 38 (2006) 323-348

\title{
TEOLOGIA E ESPIRITUALIDADE: EM BUSCA DE UMA COLABORAÇÃO RECÍPROCA
}

\author{
Alfredo Sampaio Costa, SJ
}

RESUMO: Qual a contribuição que o estudo da espiritualidade pode dar à Teologia como tal? É possível integrar estas duas disciplinas em uma harmônica sinfonia e com quais resultados? Neste trabalho procuraremos dar uma resposta a tais questões, relendo a tradição histórica de uma íntima colaboração, estudando as razões que levaram a um afastamento entre teologia e espiritualidade para tentar traçar como seria, hoje, uma teologia verdadeiramente espiritual. Uma teologia enraizada na espiritualidade seria uma teologia que cresce organicamente a partir do seu conhecimento próprio de Deus e fala sobre Deus mesmo. A espiritualidade mantém a teologia na sua vocação própria, impedindo-a de fugir ao seu objeto específico. Cabe à Espiritualidade dar à Teologia este sentido do concreto espiritual, onde o desejo de conhecer vai unido à adesão do coração de penetrar e encontrar-se com o Mistério. A função crítica da espiritualidade com respeito à teologia implica expor a teologia a um interrogatório profundo que anima o coração da luta da comunidade para permanecer fiel. Sem isso a teologia se arriscaria a perder o contato com o Deus verdadeiro que lhe deu vida.

PALAVRAS-CHAVE: Espiritualidade, Teologia, Teologia Espiritual, Teologia Mística, Colaboração.

ABSTRACT: What is the contribution which the study of spirituality can offer to Theology? Is it possible to integrate these two disciplines in a harmonic symphony, and with what results? In this study, we are trying to give an answer to such questions, re-reading the historic tradition of an intimate collaboration, studying the reasons which lead to a separation between theology and spirituality, in order to attempt to sketch what would be, today, a truly spiritual theology. A theology 
rooted in spirituality would be a theology which grows organically, from its own knowledge of God and its talk about God Himself. Spirituality maintains theology in its proper vocation, keeping it from fleeing from its specific object. It is the role of Spirituality to give Theology this sense of the spiritually concrete, where the desire to know unites with the tendency of the heart to penetrate and encounter Mystery. The critical function of spirituality with respect to theology implies exposing theology to a profound questioning which enlivens the heart of the struggle of the community to remain faithful. Without this, theology would risk losing contact with the true God who gave it life.

KEY-WORDS: Spirituality, Theology, Spiritual Theology, Mystical Theology, Collaboration.

\section{Introdução}

Toje em dia se observa um interesse crescente pela espiritualidade, e 1 em campo teológico ganha cada vez mais espaço nos currículos acadêmicos a Teologia Espiritual. Muitos estudiosos têm se debruçado sobre a árdua tarefa de tentar articular esta dimensão espiritual com o caráter propriamente científico da teologia sistemática.

Qual a contribuição que o estudo da espiritualidade pode dar à Teologia como tal? Trata-se de um aporte significativo, fundamental para a missão que a Teologia tem diante de si? É possível integrar estas duas disciplinas em uma harmônica sinfonia? E com quais resultados?

Neste trabalho procuraremos dar uma resposta a tais questões, relendo a tradição histórica de uma íntima colaboração, estudando as razões que levaram a um afastamento entre teologia e espiritualidade, para tentar traçar como seria, hoje, uma teologia verdadeiramente espiritual.

\section{A categoria de "encontro" como fundamento comum para entender a relação espiritualidade-teologia}

Mark McIntosh escreveu um sugestivo livro intitulado "Mystical Theology. The Integrity of Spirituality and Theology"1, onde apresenta os vários desafios que a espiritualidade coloca para a teologia como sendo novas possibilidades abertas à teologia. Um novo diálogo entre a teologia e a espiritualidade deveria levar a um modo novo de pensar a relação entre as duas e a caminhos frutuosos de colaboração recíproca.

${ }^{1}$ Mystical Theology. The Integrity of Spirituality and Theology, Oxford: Blackwell Publishers, 1988. 
$\mathrm{Na}$ primeira parte do seu livro, o autor tenta entender o que seja a Espiritualidade e o que está em discussão na sua relação com a Teologia. Para essa finalidade, o autor considera alguns modelos históricos onde aparece de modo claro a unidade entre Teologia e Espiritualidade, unidade que deveria estar na base desta relação como sendo o seu fundamento.

O autor parte de algumas definições de base: ele entende a espiritualidade como "a descoberta de si que se dá precisamente no encontrar-se com o outro humano e divino" 2 . A espiritualidade, entendida como "transformação e descoberta de si, dá-se sempre no encontro, é uma atividade constantemente provocada e sustentada por um outro que convoca a pessoa a sair de si mesma e penetrar a fundo na aventura da encarnação" ${ }^{\prime 3}$.

Portanto, a espiritualidade é concebida como orientada em modo inerente para a descoberta, para novas percepções e novas compreensões da realidade, em uma íntima conexão com a teologia.

A categoria de "encontro" se mostra muito adequada para designar essa nova disciplina e nos ajuda também a entender a relação que existe entre a Teologia como tal (dogmática) e a Teologia Espiritual, como veremos a seguir. Pensar a Espiritualidade em termos de um "encontro" é considerála como uma forma de vida gerada e iniciada por um Outro. Este modo de aproximar-se da Teologia Espiritual parece ser também congruente com a opinião de muitos escritores espirituais e místicos sobre si mesmos. De fato, os místicos não parecem fascinados pelos seus sentimentos, mas sim por Alguém que provoca tais sentimentos. Um exemplo: para a mística Hadewijch, a figura do Amor é central. Para ela, a experiência do Amor não é simplesmente expressão dos seus sentimentos internos. Para ela, sentir o Amor é encontrar o Amado. A sua experiência espiritual é apenas um subproduto da sua participação em Deus, uma manifestação em termos da sua humanidade da presença e da atividade secreta de Deus. Os grandes escritores místicos freqüentemente advertem contra o prestar demasiada atenção aos sentimentos ou o preocupar-se demais com os vários estados da experiência.

Se considerarmos também uma realidade mais próxima de nós, como as teologias políticas e da libertação, tais teologias puseram no centro a necessidade de a teologia não simplesmente refletir de modo doutrinal sobre a situação dos pobres à luz da Revelação, mas sim de entender a Revelação como uma matriz interpretativa, um apelo à solidariedade na qual a voz de Deus pode ser sentida na vida dos pobres mesmos. Assim, para tais teologias, é normal e, mais que isso, é necessário para a teologia emergir diretamente como uma reflexão pública sobre a espiritualidade do povo e partilhando desta. Assim escreve Gustavo Gutierrez:

${ }^{2}$ M. McINTOSH, Mystical Theology, op. cit., p. 5.

${ }^{3}$ M. McINTOSH, Mystical Theology, op. cit., p. 6. 
A experiência espiritual é o terreno no qual a reflexão teológica aprofunda as suas raízes... A solidez e a energia do pensamento teológico depende precisamente da experiência espiritual que a sustenta. Esta experiência toma a forma, antes de tudo, como um encontro profundo com Deus e a vontade de Deus. Todo discurso de fé deve partir da vida cristã da comunidade. Toda reflexão que não ajuda a viver segundo o Espírito não é uma teologia cristã... Este fato não enfraquece o rigoroso caráter científico da teologia; antes, situa-o em um modo apropriado ${ }^{4}$.

Jon Sobrino observa também:

Não é suficiente falar de Deus. A Teologia deve deixar que Deus fale. A Teologia deve mover o ser humano a falar com Deus... A Teologia mística (isto é, o discurso de Deus e não somente sobre Deus) deve ser uma mistagogia, uma introdução à realidade de Deus como Deus é: transcendência, mistério, resistente à manipulação, e ainda Pai nosso, próximo, bom e salvador. A doutrina de Deus deve respeitar sempre este mistério de Deus e introduzir neste mistério ${ }^{5}$.

Se a Teologia quer fazer bem o seu trabalho, deve preservar sempre uma espécie de transparência com este encontro com Deus no qual é radicada. Isto inclui a consciência de que Deus não é nunca um objeto que nós podemos simplesmente descrever como somos habituados a fazer com outras coisas. A Teologia precisa sempre, portanto, manter uma abertura à espiritualidade pois esta impele na direção deste encontro. Nesta perspectiva, a espiritualidade é sempre encarnada na verdadeira estrutura da realidade. Eu existo humanamente nos meus encontros verdadeiros com o real. E no centro destes encontros repousa sempre o encontro com Alguém que é a fonte contínua da realidade.

Portanto, a categoria de "encontro" poderia ser pensada inicialmente como o fundamento comum entre Espiritualidade e Teologia: A Espiritualidade como sendo a impressão que este encontro deixa enquanto transforma a vida da pessoa e a Teologia como sendo a expressão que este encontro exige quando a pessoa tenta entender e falar sobre este encontro.

\section{A ambigüidade de um termo ao longo da história}

Esta definição de Espiritualidade pode ser mantida quando se estuda a gama de significados que o termo "espiritualidade" assumiu ao longo da

${ }^{4}$ G. GUTIERREZ, We Drink Our Own Wells: The Spiritual Journey of a People, New York: Orbis Books / Maryknoll, 1986, p. 81.

${ }^{5}$ J. SOBRINO, Spirituality of Liberation: Towards Political Holiness, New York: Orbis Books / Maryknoll, 1988, p. 48. 
História? De fato, nem sempre é fácil entender de que se está falando quando se fala de "espiritualidade".

Giordano Frosini comenta que a palavra "espiritualidade" é uma palavra "da qual a nossa linguagem faz um largo uso, encontrando sempre porém uma certa dificuldade em lhe atribuir um significado preciso" ${ }^{\prime}$.

Já Jean Daniélou apontava para este perigo quando afirmava: "Quando falamos de 'espírito', quando dizemos que 'Deus é espírito', o que queremos dizer? Falamos grego ou hebraico? Se falamos grego dizemos que Deus é imaterial, etc. Se falamos hebraico dizemos que Deus é um vento forte, uma tempestade, uma força irresistível. Daqui provêm todas as ambigüidades quando se fala de espiritualidade. A espiritualidade consiste em se tornar imaterial ou em ser animado pelo Espírito Santo?"7

O termo pneumatikós (espiritual) no Novo Testamento é obviamente ligado a pneuma, entendido como Espírito de Deus. A pessoa espiritual (1Cor 2,14-15) é alguém que está sob o influxo do Espírito Santo. Não se trata de alguém que se afasta das realidades materiais ${ }^{8}$, mas sim de alguém em quem o Espírito divino habita. Neste sentido, o "espiritual" é a dimensão da vida que é gerada e sustentada por Deus. Deus é o agente primário que anima e dá nova vida à pessoa de fé. A Espiritualidade, então, não é algo que a pessoa possui, mas se trata de um novo modelo de crescimento pessoal que vai se desenvolvendo na comunidade daqueles que foram procurados, convertidos e cuidados ternamente por Cristo ressuscitado. Como afirma S. João na sua primeira carta: "O amor consiste no fato que não fomos nós que amamos a Deus, mas Ele nos amou por primeiro" (1Jo 4,10.19).

Secundariamente, o espiritual é ligado à presença ativa de Deus e não primariamente a experiências interiores extraordinárias, não obstante a presença de Deus possa certamente despertar tais sentimentos. A Espiritualidade, portanto, neste sentido primário, não se refere ao cultivo de particulares experiências interiores, mas com a nova rede de relações e percepções que a presença de Deus torna possível a toda pessoa espiritual.

Isto não significa que a experiência de cada pessoa na sua individualidade não seja importante. Mas deve ficar claro que a experiência pessoal não é em si mesma a finalidade e o escopo da espiritualidade. Isso aparece de modo evidente no Cristianismo primitivo, onde a espiritualidade é essencialmente vivida na relação com os demais na comunidade, na liturgia, orientada para Deus que se faz presente em meio à comunidade eclesial, na tentativa comum de construir o Corpo de Cristo 9

${ }^{6}$ G. FROSINI, Spiritualità e Teologia, Bologna: EDB, 2000, p. 7.

${ }^{7}$ Citado por Y. CONGAR, Credo nello Spirito Santo, I, Brescia: Queriniana, 1982, p. 18.

${ }^{8}$ G. Gutierrez mostra-se muito sensível a esta possibilidade: "A espiritualidade, como seguimento de Cristo, não significa viver a dimensão espiritual como oposta à corporal" (G. GUTIERREZ, "Bere al proprio pozzo", Concilium 18 (1982) 1343). 
Von Balthasar já tinha acenado para o fato de que na história bíblica "ninguém pode renunciar à unidade entre teologia e espiritualidade, entre conhecimento de Deus e amor de reconhecimento, nem tampouco fazer uma espécie de divisão na pessoa fiel, fazendo-a uma especialista em um dos dois aspectos"10.

A teologia patrística soube sempre com maestria manter esta profunda unidade: "Entre os Padres, seria vão e contrário às suas exigências mais íntimas separar nas suas obras os livros dogmáticos e as obras de espiritualidade [...]. Aquilo que eles ensinam eles o vivem em uma unidade tão espontânea, para não dizer ingênua, que eles ignoram totalmente a cisão moderna entre dogmática e piedade"11.

J. Leclercq confirma que a característica principal da patrística foi sempre a de ter unido de um lado o esforço da inteligência e aquele do coração, a ciência e a caridade, o conhecimento e a oração, e por outro lado, nesta experiência de luz e de fervor, o contato freqüente com as fontes cristãs fundamentais: a Escritura, as autoridades antigas, a liturgia:

Daí se pode entender a observação de um bibliotecário: 'Quando deves classificar uma obra e te encontras incerto se inseri-la no setor de teologia ou no setor de espiritualidade, pelo motivo que parece que diga respeito seja a uma que à outra, trata-se seguramente de uma obra patrística'12.

Até à Escolástica as coisas prosseguiram neste sentido: "Os Padres e os autores medievais não escolásticos não se cansavam de repetir que ninguém alcança a sabedoria (gnose) se dispõe a ela mediante uma fé viva, a ascese da mortificação e das obras, a oração contínua e se Deus não lha concede por graça"13.

Os grandes doutores não dividiam a teologia em positiva e sistemática; não subdividiam as suas exposições em setores separados, mas tratavam das diversas questões considerando-as em uma unidade coerente [...]. Nas Sumas não se faz todavia nenhuma distinção entre teologia dogmática, moral e teologia ascético-mística. Cada questão é considerada e exposta em todos os seus aspectos, sem separá-los em compartimentos estanques. A unidade da teologia é ainda mantida ${ }^{14}$.

\footnotetext{
${ }^{9}$ M. McINTOSH, Mystical Theology, op. cit., p. 7.

${ }^{10}$ Cf. H. U. VON BALTHASAR, Con occhi semplici. Verso una nuova coscienza cristiana, Roma: Herder/Morcelliana, 1970, p. 13.

${ }^{11}$ H. U. VON BALTHASAR, "Théologie et sainteté”, Dieu Vivant 12 (1948) 19. Citato por G. FROSINI, Spiritualità e Teologia, op. cit., p. 12.

12 J. LECLERCQ, Esperienza spirituale e teologia. Alla scuola dei monaci medievali, Milano: Jaca Book, 1990, p. 133.

${ }^{13}$ C. VAGAGGINI, "L'insegnamento teologico e la vita di fede, speranza e carità", Seminarium 20 (1968) 579.

${ }^{14}$ P. MOLINARI, "Bisogno di spiritualità", in CH. A. BERNARD (org.), La Spiritualità come teologia, Cinisello Balsamo (MI): Paoline, 1993, p. 28.
} 
Mas em um futuro não muito longínquo não se poderá mais manter esta unidade, quando a especialização será tão elevada que não será mais possível esperar que uma só pessoa ou obra possa fazer um tratamento sistemático de todos os setores da teologia.

Assim que, pouco a pouco, instaura-se uma divisão entre teologia dogmática e teologia moral: a primeira ocupar-se-á principalmente das coisas da fé ("de credentis"), enquanto a teologia moral interessar-se-á pela área do agir humano ("de agendis").

No século XII, o termo spiritualitas (o qual, traduzido do grego pneumatikos é o precursor do nosso termo espiritualidade) começa a ser usado não só no seu sentido primitivo, como poder de Deus que anima a vida cristã, mas como "algo que diz respeito à alma enquanto em contraste com o corpo", com uma visão muito negativa da corporeidade.

Este fato levou a uma tendência privatizante na história do cristianismo: a Espiritualidade começou a se referir a um estado refinado da alma focalizando principalmente como uma pessoa alcança estes estados superiores de pureza e exaltação. Durante os séculos XVI e XVII dá-se uma mudança profunda no termo "espiritualidade", que passa a significar as disposições interiores de uma pessoa, ou, em outras palavras, o seu estado de ânimo. Um certo momento de crise dá-se em 1695 com a condenação do Quietismo de Madame Guyon, cujos ensinamentos, sem dúvida, recomendando a resignação extrema e o desconectar do mundo exterior provocou uma suspeita com relação a um tipo de espiritualidade muito refinada, rara e separada da vida cristã ordinária.

Quase como uma reação a esta posição quietista, um novo foco de espiritualidade se desenvolveu na linha de uma teoria da luta individual pela perfeição. E em continuidade com esta pesquisa neo-escolástica de ordem e de classificação havia uma grande profusão terminológica. O termo "Teologia Mística" foi apropriado de Dionísio Areopagita. Mas se para esse autor o termo se referia ao conhecimento revelado aos cristãos quando eles são transformados por Deus, agora este termo passa a ser utilizado como um termo técnico para o ensino teórico sobre o processo de santificação da alma. Concebida deste modo, a espiritualidade poderia ser classificada como uma sub-especialização da teologia moral, a qual, enquanto importante para o crescimento da alma individual, muito dificilmente poderia ser imaginada como uma fonte de conhecimento teológico. A dimensão mística da vida espiritual permanece muito isolada da teologia: ao invés de ser considerada como a dimensão mais profunda da espiritualidade, a dimensão mística acaba por ser vista como uma recompensa da graça após a luta ascética, ou ainda, como um conjunto suspeito de experiências paranormais e de comportamentos estranhos.

Por este motivo, a atitude da modernidade com relação ao místico deveria ser o de querer eliminar o misticismo como um elemento improdutivo, 
muitas vezes falsamente rotulado como quietista, irracional e oculto. Como reação, o misticismo desenvolveu uma linguagem e uma lógica próprias que por sua vez apareciam como ininteligíveis para a racionalidade cultural.

Assim a dimensão mística da espiritualidade cristã, aquele conhecimento transformante que os primeiros escritores cristãos viam como sendo o verdadeiro fundamento da teologia, acaba por crescer cada vez mais estranho à teologia.

No século passado, o termo "Teologia espiritual" era muitas vezes utilizado de modo intercambiável com "Teologia ascético-mística". Na metade do século passado, o termo "Espiritualidade" começa a adquirir uma maior popularidade. Este desenvolvimento coincide com um enfoque mais existencial e amplo da espiritualidade, articulando as experiências de transcendência dos fiéis, incluindo todos os aspectos da vida e ultrapassando os limites de religiões e culturas. Assim, a perfeição passa a ser vista como o perscrutar o complexo mistério do crescimento humano no contexto de uma relação viva com o Absoluto. Enquanto este modo mais recente de entender a espiritualidade é muito mais flexível e aberto a muitas perspectivas de pesquisa - psicológico, fenomenológico, sociológico etc. - a sua relação com a teologia permanece problemática.

As definições de espiritualidade enquadradas em termos assim tão gerais como a busca humana por uma transcendência, realização e autenticidade torna difícil a tarefa de distinguir a espiritualidade da religião em geral, ou ainda, da vida ética.

A espiritualidade parece então perder a sua voz teológica e passa a ser vista como uma particularmente potente expressão da subjetividade humana. Contemplar a espiritualidade exclusivamente em termos de "subjetividade" acaba por excluir as implicações teológicas presentes na transformação do sujeito. Deste modo, a presença do Outro divino acaba por se dissipar por detrás de um ou de outro aspecto da autoconsciência humana. Para dar um exemplo: Ao se falar do progresso espiritual da alma, tal avanço seria interpretado simplesmente em termos de uma subida da mente na direção de uma mais pura forma de consciência (comum a muitas tradições religiosas), perdendo-se de vista o que implica para a existência humana a sua relação com o Ser divino.

Este enfoque é imensamente (e talvez sedutoramente) atraente: primeiro porque ele permite o estudo da espiritualidade puramente em termos de ciências humanas. Depois pelo fato que parece ser muito moderno e ecumênico. Este modo de ver as coisas representa um crescente consenso dentro do campo de estudo da espiritualidade. Contudo, é preciso examinar se esta perspectiva não corre o risco de fechar prematuramente a possibilidade de uma contribuição da espiritualidade à reflexão teológica. 


\title{
Problemas decorrentes da separação espiritualidade-teologia
}

No Cristianismo primitivo, a espiritualidade se entendia dentro de uma matriz comunitário-litúrgica: como um crescimento em uma nova rede de relações onde o esforço para amar tudo o que é humano em todos os seus aspectos e diferenças se torna o processo por meio do qual a pessoa penetra no conhecimento e amor de Deus.

O centrar-se das épocas posteriores sobre as experiências interiores que se dão ao longo deste processo de encontro levaram ao nascimento de uma elaborada "ciência" da alma, primeiro segundo categorias neo-escolásticas, e depois, recentemente, de modo cada vez mais psicológico e antropológico. Este processo levou a uma compreensão da espiritualidade que não deixa ver muito claramente quem é o autor que gera todo este processo de transformação.

Ora, uma teologia sem espiritualidade se torna uma teologia muito refinada metodologicamente, mas incapaz de conhecer ou de falar dos mistérios que estão no centro do Cristianismo; a espiritualidade por sua vez, sem a teologia, como que perde as suas raízes e acaba facilmente vencida pelo consumismo individualista.

\begin{abstract}
A contemplação, longe de ser oposta à teologia, constitui de fato a perfeição normal da teologia. Nós não devemos separar o estudo intelectual das verdades divinamente reveladas e a experiência contemplativa destas verdades como se uma coisa não tivesse nada que vez com a outra. Trata-se de dois aspectos da mesma realidade. Teologia dogmática e teologia mística, ou teologia e espiritualidade, não devem ser separadas como categorias que se excluem reciprocamente, como se o misticismo fosse algo somente para mulheres pias e o estudo teológico fosse para homens práticos mas não santos. Esta divisão falaz talvez explique muito do que se estaria perdendo em ambas: na teologia e na espiritualidade. Se elas não estão unidas, não há fervor, não há vida e não há um valor espiritual na teologia e nem tampouco pode haver substância, significado e uma orientação segura na vida contemplativa ${ }^{15}$.
\end{abstract}

O encontro transformador com Deus, que hoje se costuma chamar com o nome de espiritualidade ou mística, nas épocas mais antigas era muito mais expresso pelo termo "contemplação", termo que reúne dois elementos que nós vemos muitas vezes em contraste como se fossem excludentes, ou seja, o impulso afetivo e o impulso intelectual ou cognoscitivo. Já Ricardo de S. Vitor afirmava: "A contemplação é uma livre e clara visão da mente fixada sobre a manifestação da sabedoria em uma maravilha suspensa".

${ }_{15}$ Th. MERTON, Seeds of Contemplation, Anthony Clarke Books, 1972, pp. 197-198. Citado por A. LOUTH, Theology and Spirituality, revised edition, Oxford: SLG Press, 1978, p. 4. 
Nesta definição encontramo-nos com três pontos vitais:

1) A contemplação é vista como uma atividade na qual a mente é libertada para perceber claramente, livre das constrições da distração, das preocupações e dos preconceitos.

2) O uso do termo "mente" aqui não deveria sugerir o que é exclusivamente discursivo. A noção mais clássica de "mente" se refere ao desejo de todo o nosso ser por uma profunda compreensão e relação com tudo o que é inteligível.

3) Esta compreensão da "contemplação" afirma que o ato contemplativo não é em primeira instância um momento de sentimentos especialmente excitados, mas muito mais um evento de ser compreendidos pelo desvelar da consciência. Assim que a contemplação não tem nada que ver com algo que a pessoa faz, mas se refere a um evento que a pessoa é chamada a penetrar. $\mathrm{O}$ evento da contemplação é portanto um novo entendimento, um novo encontro com a sabedoria. É eminentemente um evento teológico.

Tomando em consideração este conceito de "contemplação", Louth afirma que é exatamente na contemplação que a espiritualidade e a teologia se encontram. A Teologia é um dos frutos da contemplação, como a tentativa de expressar e de articular aquilo que é percebido nesta "clara e livre visão"; já a Espiritualidade é a preparação da alma para a contemplação.

Em tal visão das coisas, a Espiritualidade aparece como intrinsecamente orientada à Teologia e a Teologia como organicamente emergente da Espiritualidade. As duas estão ligadas uma à outra como sendo uma "a preparação para" e a outra "a articulação de" este evento da contemplação, o mais íntimo encontro com Deus.

A separação é nociva para ambas: Tende a desorientar a espiritualidade, privando-a da sua referência última, tornando-a assim susceptível aos ídolos, às constrições ou medos do indivíduo. Além do mais, a intensidade da experiência mística pode facilmente levar a um tipo de absolutismo que oprime a vida dos místicos ou ainda das culturas receptivas a eles. A teologia recorda à espiritualidade que "a interpretação é intrínseca à experiência"16. Toda consciência espiritual necessita ser contextualizada e avaliada a partir do seu ambiente: não existe nunca uma experiência pura e absoluta, livre de uma matriz interpretativa de uma determinada cultura!

O divórcio entre Teologia e Espiritualidade implica uma séria lacuna: como ambas cresceram focalizando cada uma delas uma esfera respectiva (a experiência interior de uma parte, os critérios de um ensinamento científico da outra parte), a teologia se sentiu particularmente menos segura do

${ }^{16}$ H. EGAN, Christian Mysticism: The Future of a Tradition, New York: Pueblo Publishing Company, 1984, p. 376. 
que fazer exatamente com a vida espiritual dos teólogos e com os textos dos escritores espirituais. As questões que os místicos levantavam à Teologia embaraçavam muitos teólogos acadêmicos.

A vasta gama de fontes espirituais disponíveis à Teologia (desde os modelos concretos de uma vida de santidade às imagens particulares de um texto místico) dificilmente pode ser ignorada se a teologia deve levar a sério a sua tarefa de articular um entendimento crítico da fé da comunidade cristã. Como analisar, por exemplo, o significado da pessoa de Jesus Cristo sem levar em consideração o significado encarnado que Jesus representa para um mártir ou na consciência de um místico, especialmente se eles definiram a sua missão em termos de uma participação em Cristo $^{17}$ ?

Von Balthasar chamou a atenção para o fato de que os teólogos, sem a espiritualidade, podem acabar por perder também a habilidade de falar sobre doutrinas do Cristianismo, uma vez que tais doutrinas não são concebidas somente como proposições a serem analisadas, mas também como mistérios a serem encontrados. $\mathrm{O}$ Deus sobre quem eu quero falar não pode nunca ser somente um objeto para as intrincadas teorias que os teólogos desejam propor.

Para penetrar no mistério de Deus não necessitamos de informações... mas necessitamos ser alcançados por Deus mesmo, necessitamos ser chamados por Ele a partilhar do seu conhecimento... é a iniciativa de Deus que se requer. Mais do que aquilo que nós devemos falar sobre Ele, interessa aquilo que Ele deveria falar a nós ${ }^{18}$.

\section{A integração histórica entre espiritualidade e teologia}

Desejamos aqui examinar alguns exemplos na história do cristianismo que mostram como seria esta integração entre espiritualidade e teologia.

O teólogo ortodoxo Vladimir Lossky defendia que "nós devemos viver o dogma de um modo tal que ao invés de assimilar o mistério ao nosso modo de entender nós deveríamos, antes, buscar uma mudança profunda e uma transformação interior do Espírito que nos torne capazes de experimentá-lo misticamente ${ }^{\prime \prime 19}$.

A preocupação da Espiritualidade é sempre com a "possibilidade, o modo ou os meios da nossa união com Deus ${ }^{\prime 20}$. Ela procura avaliar todos os

\footnotetext{
${ }^{17}$ Ver o interessante trabalho de W.M. THOMPSON, Fire and Light: The Saints and Theology. On Consulting the Saints, Mystics, and Martyrs in Theology, New York: Paulist Press, 1987 e Christology and Spirituality, New York: Crossroad, 1991.

${ }^{18}$ H. McCABE, OP, God Matters, London: Geoffrey Chapman, 1987, p. 20.

${ }^{19}$ V. LOSSKY, The Mystical Theology of the Eastern Church, New York: St. Vladimir's Seminary Press, 1976, p. 8.

${ }^{20}$ V. LOSSKY, The Mystical Theology of the Eastern Church, op. cit., p. 8.
} 
discursos teológicos, enquanto tais discursos salvaguardam a possibilidade para todos os cristãos de se tornarem "co-participantes da natureza divina" (2Pd 1,4).

O discurso da Teologia deve provir sempre do Mistério de Deus, que nunca pode ser transformado em um objeto de estudo da teologia, mas que permanece sempre como o Sujeito ativo. Para a Espiritualidade, o discurso da Teologia é a linguagem para descrever e participar deste encontro com Deus. Portanto, a Teologia deveria não somente saber escutar os escritores místicos e a sua teologia, mas também procurar aprofundar-se na doutrina cristã mostrando como ela orienta a experiência cristã de Deus e, ao mesmo tempo, é formada por esta mesma experiência.

Já no ambiente neoplatônico, o processo de conhecer Deus era certamente entendido como incluindo uma adesão amorosa a Cristo. Segundo essa corrente, uma pessoa começa a entrar na presença de Deus precisamente quando sai de si mesma para seguir a Cristo.

No Cristianismo primitivo, a relação com Cristo é transposta para uma dimensão de contemplação: "E todos nós, com o rosto descoberto, refletindo como em um espelho a glória do Senhor, seremos transformados naquela mesma imagem, de glória em glória, conforme à ação do Senhor que é Espírito" (2Cor 3,18). A palavra que é aqui traduzida por "refletindo" (katoptrizomenoi) foi muitas vezes entendida como "mirando" ou "contemplando" (speculantes). Portanto este texto poderia ser lido de modo a significar que é por meio da contemplação da glória de Cristo ressuscitado que a imagem de Deus em nós se torna conformada ao Verbo.

O conhecimento último de Deus se dá por meio de uma amizade com Cristo, que inclui mente e coração. As atividades contemplativas do conhecimento e do amor são interpretadas pelos primeiros cristãos em termos de uma participação do mistério pascal: "Se de fato nos tornamos um mesmo ser com ele por uma morte semelhante à sua, sê-lo-emos igualmente por uma comum ressurreição" (Rm 6,5). Esta co-participação nos sofrimentos de Cristo tornase uma chave de interpretação crucial para vários escritores místicos.

A nossa palavra "místico" vem do grego "mustikos", um qualificativo derivado do verbo "muo" que significa "fechar" (especialmente "fechar os olhos"). Refere-se a tudo o que é secreto, escondido. Este termo era ligado aos cultos mistéricos helenísticos: portanto, o místico designava os rituais secretos dos cultos onde era proibido revelar os segredos às pessoas não iniciadas. A ênfase aqui parece ser não sobre um conhecimento secreto com respeito à Realidade Última, mas simplesmente o segredo com o qual as práticas rituais eram protegidas.

É surpreendente encontrar que quando os autores cristãos utilizam este termo, o seu uso inicial não tinha nada a ver com atividades rituais secre- 
tas, mas principalmente com a Bíblia. Clemente (c. 150 - c. 215) e também Orígenes (c. 185 - c. 254) parecem, sobre este ponto, seguir a Filo (c. 20 AC - c. 50) que já aplicava o termo "místico" no sentido de "significado profundo escondido nas Escrituras".

Para Filo, de fato, o Logos divino é o foco de interpretação a partir do qual toda a Escritura é interpretada. Clemente e Orígenes, crendo que Cristo é a encarnação do Verbo, seguirão o mesmo caminho. Para eles, toda a história do povo de Deus narrada nas Escrituras encontra o seu significado secreto revelado e articulado em Cristo. Ler as Escrituras com esta aspiração de permitir a Cristo revelar o que era escondido é precisamente o que é referido como sendo a "interpretação mística" das Escrituras.

Cristo é a chave interpretativa que abre um vasto tesouro de significados. O processo exegético de chegar a este novo conhecimento é referido como "místico" e o conhecimento ao qual se chega é chamado de "conhecimento místico". Assim sendo, o processo exegético se torna uma aventura espiritual na qual a comunhão com o Cristo vivente, o qual é encontrado na meditação da Escritura, conduz o cristão até Deus. Neste sentido, reafirmamos que "místico" não diz respeito à experiência interna do cristão, mas sim ao significado escondido e a esta nova compreensão que transforma a vida e que se dá no encontro com Cristo.

Para os Padres gregos, a palavra "místico" era utilizada antes de tudo para descrever a realidade divina que Cristo nos trouxe e que nos é revelada no Evangelho, verdade que dá um profundo e definitivo significado a todas as Escrituras. De agora em diante, "místico" passa a designar todo conhecimento das coisas divinas ao qual a pessoa acede por meio de Cristo; conseqüentemente, o termo passará depois a ser aplicado às coisas mesmas, às práticas que tornam viável esta união com Deus.

Enfim, o termo ganhará ainda uma maior difusão passando a determinar todos os ensinamentos ou doutrinas que tocam os pontos mais difíceis ou misteriosos da fé cristã.

Para S. Paulo, "místico" diz respeito em primeiro lugar à vontade de Deus escondida, e agora revelada, de reunir todas as coisas em Cristo (Ef 1, 910). O evangelho do amor de Deus pela humanidade é secreto, "místico", porque é a manifestação do amor de Deus e é sempre pleno de uma insondável profundidade de riquezas de significado.

O que torna este amor "místico" ou escondido, além de toda compreensão, não é o mero fato da sua infinidade, mas o fato de que esta infinidade revela a si mesma na atividade do amor que doa a si mesmo, na decisão de Deus de não ser um Deus longínquo, mas próximo à sua criação. Este derramamento infinito de amor salvador é inexaurível e inacessível no seu verdadeiro evento do seu ser, mas é estado revelado e dado a conhecer na 
vida, morte e ressurreição de Cristo. Portanto, o que é mais misterioso não é o ser divino em si mesmo, mas precisamente a autodoação de Deus que é a característica fundamental da Trindade divina. Cristo, como agente do mistério do amor divino vai à procura do povo de Deus "misticamente", isto é, por meio do desvelar-se do evangelho nas palavras veladas da Escritura e dos atos litúrgicos. Assim, por extensão, a atividade pela qual este significado escondido se revela na vida da comunidade é também chamada de "místico". Ora, este é muito mais um evento comunitário que uma experiência privada. Trata-se, de fato, da transformação da vida da comunidade em resposta ao plano de salvação de Deus. O estado psicológico interior dos indivíduos envolvidos não é, de modo algum, coligado a este significado primigênio do termo "místico".

Finalmente, o "místico" será aplicado também à Igreja, enquanto ela participa da morte e ressurreição de Jesus. Para os primeiros cristãos, de fato, a Igreja não é outra coisa que o mundo em via de transformação como a presença mística de Cristo tem como efeito a recriação de todos os membros do seu Corpo ${ }^{21}$.

\section{Dionísio Areopagita: o papel da teologia é conduzir a comunidade dos fiéis à união com Deus}

A primeira pergunta que devemos enfrentar é: como se deu a passagem desta primeira noção de teologia mística assim tão comunitária, prática, orientada na direção da atividade de Deus em meio à Igreja, à nossa concepção moderna da mística como sendo algo que diz respeito aos estados individualísticos das experiências interiores as mais altas?

A resposta usual aponta um dedo acusador na direção de um conjunto de textos misteriosos, provavelmente compostos no fim do século $\mathrm{V}$ ou início do século VI por um autor desconhecido que se identificou como o ateniense convertido por S. Paulo, Dionísio Areopagita, mencionado nos Atos dos Apóstolos $(17,34)$.

Dionísio exerceu um fascínio muito grande sobre as gerações de teólogos devido ao seu modo de falar da irradiação da glória divina, de como a Igreja manifesta esta luz ao mundo. Mas talvez não terá sido a adoção feita por ele do pensamento neoplatônico posto a serviço da teologia cristã o fator que levou a espiritualidade cristã a perder de vista a sua impostação comunitária e escriturística?

${ }^{21}$ Cf. O. CLEMENT, The Roots of Christian Mysticism, New York: New City Press, 1995, p. 95. 
Vejamos alguns exemplos que pareceriam confirmar a idéia de uma mística como um estado visionário de experiência interior:

Ao descrever o seu amado mestre, Dionísio observa que o que o diferenciava das outras grandes figuras era a profundidade da sua experiência espiritual. Ele superava, depois dos teólogos, todos os demais santos iniciadores: "sendo completamente arrebatado, completamente fora de si e tomando parte e entrando em comunhão com as coisas que ele louvava... foi considerado um arauto divino inspirado por Deus" ${ }^{\prime 22}$.

Este trecho certamente soa como se o ponto central da mística repousasse sobre uma experiência interior de um indivíduo que recebe uma graça especial.

Os estudos recentes de Andrew Louth e Paul Rorem nos sugerem que esta construção é um anacronismo, uma sobreposição da nossa concepção moderna de mística sobre uma prática mais antiga. Sem dúvida Hieroteu é descrito como alguém que tem uma experiência extraordinária. Mas quando comparamos a linguagem usada aqui com o modo de falar de Dionísio em outros escritos, este modo de falar pareceria sugerir não tanto um estado interior mas muito mais um contexto litúrgico ${ }^{23}$. De fato, é preciso notar que o termo grego utilizado por ele é koinonia, termo que é utilizado para designar oficialmente a eucaristia; além do mais, as "coisas louvadas" que são citadas no texto são identificadas em outros textos como "o pão e o cálice", o que reforçaria o contexto celebrativo da experiência ${ }^{24}$. Portanto, parece que se poderia argumentar que a profundidade mística não é alcançada por meio de uma ascensão puramente interior da alma individual (como afirmavam os neoplatônicos), mas que agora nos encontramos em um contexto novo, onde o itinerário neoplatônico vem recontextualizado na vida sacramental da comunidade.

E o que poderíamos dizer do texto que fala de Hieroteu como sendo arrebatado em êxtase? Esta linguagem precede imediatamente a referência à comunhão (koinonia), portanto não se poderia dizer que o Areopagita considere o êxtase como sendo uma experiência privada ou puramente emocional. De fato, a referência mais clara que encontramos nos escritos de Dionísio sobre o estado de êxtase se encontra na sua análise do dinamismo da Escritura. Dionísio explica que ele prefere falar de Deus usando uma linguagem dialética de negação, onde uma noção é sempre superada pela noção seguinte:

A Divindade está acima de todas as coisas... para celebrar verdadeiramente o Uno supremo e a sua divina fecundidade, o chamamos de Divindade que

${ }^{22}$ I Nomi Divini, DN 684 A.

${ }^{23}$ Cf. P. ROREM, Biblical and Liturgical Symbols within the Pseudo-Dyonisian Synthesis, Studies and Texts 71, Toronto: Pontifical Institute of Medieval Studies, 1984, especialmente pp. 133-138.

${ }^{24}$ Pode-se ver por exemplo La Gerarchia Ecclesiastica, EH 428 A-B. 
supera todo nome com o nome de trino e uno enquanto essência que supera todos os outros seres... A suprema divindade de Deus supera todas as coisas... Dele não existe nome nem palavra... nem mesmo o nome de Bondade podemos atribuir a ele de modo adequado, mas somente pelo desejo de entender e de dizer algo em torno àquela natureza inefável. Ainda que lhe consagrássemos o mais venerado dos nomes... permaneceríamos sempre muito longe da verdade das coisas. Por essa razão muitos autores preferiram usar a via da negação, enquanto separa a alma dos pensamentos que lhe são naturais e a guia através de todos os pensamentos divinos, dos quais é bem distante aquele que ultrapassa todos os nomes, discursos e ciência, por quanto seja possível ao nosso ser de unir-se ao seu ${ }^{25}$.

Analisando este trecho vemos que o êxtase para Dionísio não tem um sentido puramente psicológico, mas deveria ser entendido em um sentido noético: um ser conduzido para além dos ídolos do pensamento que devem ser deixados para trás durante o Êxodo da comunidade na direção de uma relação mais profunda com Deus.

Para entender bem o pensamento de Dionísio, é preciso estudar em profundidade duas das suas noções centrais:

- O modo como ele considerava o cosmos e a Igreja como irradiações da glória divina: o que faz com que o cosmos seja uma teofania hierárquica não é simplesmente o fato de que ele é estruturado segundo uma ordem, mas o fato de que os membros da estrutura são animados pelo desejo de Deus pelo outro, mediatizando o desejo de Deus pela felicidade última do outro. Neste sair de si do amor de Deus estão implicados dois movimentos co-relativos: de uma parte o amor extroverso de Deus e da outra parte a intenção de Deus de abraçar e elevar o outro à vida divina. Estes dois movimentos são na verdade dois aspectos diversos de um único movimento divino. Isto se revela na pessoa de Jesus: Cristo encarna ambos os movimentos: o amor descendente de Deus à procura do outro e o amor ascendente de Deus através do outro, elevando e atraindo a pessoa para o abraço da paz. Para Dionísio, a Teologia é a atividade comunitária de reconhecer e de responder a esta presença mística ou escondida de Deus.

- A sua noção de Teologia como atividade interpretativa por meio da qual a comunidade busca penetrar nas profundezas escondidas da glória divina: isto é para Dionísio a Teologia Mística, teologia que realiza a si mesma levando a comunidade à realidade insondável do Deus Amor. A Revelação é a manifestação do desejo de Deus de sair de si para se relacionar com o outro. A tarefa da Teologia é passar através destes sinais da presença de Deus e penetrar assim mais a fundo no seu Mistério.

${ }^{25}$ I Nomi Divini, DN 981 B. 
Talvez a mais famosa descrição deste processo é o breve escrito de Dionísio intitulado "Teologia Mística". A estrutura deste trabalho revela a sua visão da realidade e de como ele entendia a tarefa da Teologia. Dionísio abre o seu escrito com uma oração a Deus Trindade, Fonte de vida de toda a Criação e de todos os sinais de verdade que podemos encontrar no Cosmos (de modo especial manifestado na Escritura e na liturgia).

Dionísio suplica à Trindade que nos conduza do não-conhecimento à luz, alcançando o vértice mais alto da experiência mística ${ }^{26}$. Portanto, no seu modo de pensar, a Teologia deveria, dum modo totalmente existencial e prático, percorrer estes mesmos níveis do autodesvelar-se divino, sendo atraída através de cada um deles ao significado mais profundo que se encontra sempre para mais além de cada degrau.

O modelo deste processo é Moisés, na sua subida na direção da obscuridade mística do não-conhecimento. Dionísio descreve a subida de Moisés com termos que representam o ingresso do celebrante no coração do mistério litúrgico; portanto, o exemplo de Moisés não é a descrição de uma experiência interior de um indivíduo isolado, mas muito mais um modelo para a consciência crescente de uma comunidade litúrgica como esta vive o rito eucarístico e ao mesmo tempo reflete sobre o seu processo de uma participação sempre mais profunda no mistério da oblação de si de Jesus. Depois de ter apresentado Moisés como o contexto próprio e seguro para o processo teológico, Dionísio passa a refletir mais teoricamente sobre uma transição crucial: a mudança das afirmações descendentes do auto-revelarse de Deus às negações ascendentes correlativas. Para Dionísio, de fato, o caminho apofático ocorre quando a comunidade cai na conta do significado escondido nos símbolos:

Na medida em que penetramos naquela Obscuridade que o entendimento não pode entender, então chegamos a um ponto em que nos encontramos não só dizendo poucas palavras, mas ainda mais, em um silêncio perfeito e sem pensar em nada;

Quanto mais subimos e nos aproximamos do cume, as palavras se fazem mais escassas. Quando alcançaremos o pico, reinará um profundo silêncio. Seremos completamente unidos ao Inefável (MT 1033 C).

A Teologia cumpre o seu trabalho quando é capaz de conduzir a comunidade dos fiéis para além do ponto onde as palavras podem alcançar. $\mathrm{O}$ ponto crucial está no fato de que o estádio final desta viagem não é um silêncio que é "nada" e "vazio" de significado, mas muito mais um silêncio de abraço, de união com Deus.

Conclusão: Longe de uma concepção de mística como uma série de estados interiores da experiência, Dioníso entende a vida mística essencialmente

${ }^{26}$ Cf. Teologia Mistica 997 A-B. 
como uma viagem dentro das profundidades de significado implícito em todas as manifestações do amor de Deus. A Teologia Mística consiste, portanto, no discernimento desta presença escondida (mística) e na tentativa de alcançar um entendimento do que Deus deve ser se Ele verdadeiramente ama o mundo a ponto de criá-lo e de se fazer presente em meio a este mundo em Cristo.

\section{Máximo, o Confessor: o papel da teologia é levar à divinização por meio de Cristo Verbo de Deus}

Dionísio ofereceu um modelo fértil para a fé em busca de compreender. $\mathrm{Na}$ sua concepção, como vimos, este irradiar-se cósmico e eclesial do amor divino constituía a dinâmica interna da mesma teologia. Para ele, a Teologia tem necessidade de descobrir a sua verdadeira identidade, que consiste precisamente no inserir-se como um aspecto dentro desta viagem mística por meio da qual Deus está re-conduzindo toda a Criação à unidade com o amor divino.

Alguns pontos se devem ainda esclarecer em uma visão tal de Teologia mística. Talvez os principais seriam estes dois:

- Qual é a natureza deste conhecimento dito "místico", especialmente se entendido em termos de um estado último da alma na sua união com Deus?

- Qual é o papel que Cristo tem neste processo místico?

Para tentar responder a estas perguntas, veremos como São Máximo, o Confessor (580-662) tratou destas questões.

\section{Conhecimento místico.}

Assim como para Dionísio, também para Máximo a força que move a Teologia mística é o Amor divino. Seguindo a Evágrio Pôntico (séc. IV), Máximo assume que estes últimos graus de conhecimento somente podem ser alcançados quando a mente desenvolve o desapego das coisas e é capaz de discernir os princípios interiores (logoi) de todas as coisas. Tal conhecimento se alcança penetrando no significado escondido ("místico") das coisas. É preciso não esquecer que para Máximo os místicos logoi presentes em todas as coisas criadas eram como sussurros do Logos, o Verbo divino, que é a fonte de toda a Criação. Nos níveis mais altos do Amor a pessoa chega a um conhecimento porque a mente recebe uma impressão da vida divina diretamente do Logos. Só a pessoa contemplativa pode ver todas as coisas a partir da sua fonte interior, o Logos. Portanto, este conhecimento é sempre um conhecimento contemplativo, porque é um conhecimento desfrutado a partir da perspectiva divina: trata-se de um conhecimento simples e indiviso, modelado segundo o conhecimento de Deus. 


\section{O papel de Cristo na união com Deus.}

A Ressurreição de Cristo é central para o pensamento de Máximo, o Confessor. O seu ensinamento sobre a divinização do homem é uma expressão da sua confiança em que o mistério do Verbo encarnado é uma realidade atuante, atraente e dotada de um grande poder transformador. De fato, Máximo declara que o que diviniza o crente é o partilhar do mistério da morte e ressurreição de Cristo. O mistério da Encarnação é a chave interpretativa que desvela a presença de Deus na teofania do cosmos e da Igreja.

"O Verbo de Deus e Deus querem sempre e em tudo operar o mistério da sua Encarnação" 27 . Cristo é "Aquele que desejava a salvação de todos os homens, tendo fome da sua divinização"28.

O contexto destes trechos não deveria nos fazer pensar que a vontade divina fosse somente em relação com a queda do homem e a economia salvífica do Verbo encarnado. Este projeto era já aquele de Deus criando o homem e constitui na verdade a finalidade da sua criação:

“Com efeito, é para isso que Ele nos fez, para que nós pudéssemos participar da natureza divina" (2Pd 1,4), participantes da sua eternidade e para que nós fôssemos semelhantes a Ele segundo a divindade que vem da graça, pela qual se dá a constituição e a permanência dos seres e a produção e a criação das coisas que existem" ${ }^{\prime 29}$.

Máximo considera o crente como sendo conduzido por Cristo aos mais altos níveis de conhecimento místico. Afirma que se nós seguimos a Cristo, que passou em meio a todas as coisas, também nós passaremos por meio de todas as coisas e o conheceremos na sua glória. Esta presença mística de Cristo na alma situa o movimento de elevação da Teologia em um contexto cristológico muito bem definido: é Cristo que desperta o crente e põe em movimento a sua ascensão até as profundidades de Deus.

No seu comentário sobre a Oração do Senhor, Máximo afirma que "Cristo põe em nós um desejo insaciável por Ele, que é o Pão da Vida, a Sabedoria, o Conhecimento e a Justiça" ${ }^{\prime 30}$. Seguindo o modelo da união hipostática na Encarnação, Máximo vê a realização última humana como o ter a nossa natureza humana re-configurada de acordo com o modelo da vida do Filho: do mesmo modo como a humanidade de Cristo é ordenada segundo o modelo da vida e da missão do Filho, a nossa humanidade alcança a sua realização à medida que participa em Cristo. A Pessoa do Verbo transfigu-

\footnotetext{
${ }^{27}$ PG 91, 1084CD.

${ }^{28}$ PG 90, 309D.

${ }^{29}$ Ep. 24, PG 91,609 C.

${ }^{30}$ PG 90, 905 CD.
} 
ra a alma e a conduz a uma nova relação com o Pai. Máximo concebe a divinização como um processo de subida da alma, por meio da sua formação em Cristo, até o Pai. É como se fosse uma nova criação: o ser humano é impulsionado à harmonia com a missão do Filho eterno. Em tal contexto, a Teologia Mística pareceria implicar uma transformação do entendimento humano, isto é, uma percepção nova da realidade a partir da sua fonte trinitária e um refletir sobre a realidade na sua relação com a auto-doação de amor da parte de Deus.

Conclusão: Para os primeiros cristãos, o lugar que a Teologia ocupa é o que estabelece a participação da comunidade em Cristo. Isto implica uma transformação da consciência por meio de um árduo trabalho de crescimento espiritual, abertura recíproca à presença do divino escondida nas lutas quotidianas e nos rituais da vida eclesial.

\section{A descoberta da interioridade: espiritualidade como algo privado e particular}

Como vimos, a Teologia Mística, ao menos no seu período inicial, era um aspecto central da vida eclesial, "fruto da participação do mistério de Cristo, o qual é inseparável do Mistério da Igreja" ${ }^{31}$. Não é por coincidência que este período em que a Igreja se encontrava mais profundamente inserida no Mistério de Deus em Cristo fosse também o período no qual se formasse o pensamento doutrinal cristão. As doutrinas básicas sobre a Trindade e a Encarnação, elaboradas nestes séculos, são doutrinas místicas formuladas dogmaticamente. Foi neste contexto da participação da comunidade no mistério pascal que a Igreja começou a se concentrar mais sobre o significado de Jesus e, portanto, a entender um pouco mais da fonte escondida de toda vida, revelada no amor de autodoação de alguém que morre na cruz.

Mesmo quando a Igreja primitiva tratava de algo tão pessoal e individual como a transformação do coração da pessoa, a ênfase não cai sobre o privado e o particular, mas sim sobre uma realidade (o Mistério de Deus em Cristo) que chama a pessoa a viver em uma comunidade (a Igreja) e dá uma identidade e uma estrutura à experiência de cada indivíduo, não podendo nunca ser reduzida a tal experiência individual, que será sempre uma experiência limitada ${ }^{32}$.

Mas o que acontece quando as estruturas da vida eclesial não estão mais em condições de sustentar esta integridade do encontro pessoal e de significado público? Não se tornaria então mais difícil para a experiência

${ }^{31}$ A. LOUTH, Origins of the Christian Mystical Tradition, New York: Oxford University Press, 1983, p. 200.

${ }^{32}$ Cf. R. WILLIAMS, The Wound of John of the Cross, 2nd edition, Cambridge, Massachusetts: Cowley Publication, 1991, p. 3. 
individual de ser incorporada e encontrar uma identidade e estrutura por meio de uma impostação comunitária?

Ora, essa poderia ser uma possível leitura da história da teologia dogmática e da teologia mística no decorrer da Idade Média. Durante o período da Escolástica, aconteceram mudanças na conjuntura da espiritualidade cristã que tornaram mais difícil a comunicação entre Teologia e Espiritualidade. Na espiritualidade medieval, o Eu começa a ser construído cada vez mais em termos de vida interior, de experiência e de afetividade. Assim a participação no mistério de Deus em Cristo passa a ser visto como algo que faz parte da esfera do privado e do particular.

Este focalizar da espiritualidade medieval sobre a experiência individual e sobre a afetividade levou a uma crescente desconfiança entre Teologia e espiritualidade que perdura até hoje. As práticas de piedade e as devoções, já a partir do século XI, tornam-se uma devoção privada e pessoal. Dá-se um interesse cultural crescente sobre a autoconsciência e sobre os sentimentos interiores. No campo teológico também ocorrem mudanças no modo de tratar alguns temas, como por exemplo a escatologia: as antigas fórmulas centravam-se sobre a vitória cósmica de Cristo sobre o pecado e a morte; na Alta Idade Média, o interesse muda, centrando-se mais sobre os sofrimentos físicos de Cristo na crucifixão como expiação da culpa do indivíduo pecador.

As expectativas quanto ao Fim parecem também mudar de uma esperança na recapitulação de todas as coisas em Cristo na direção de uma preocupação pelo destino do indivíduo ${ }^{33}$.

Um desenvolvimento paralelo se dá na espiritualidade no que diz respeito à compreensão da vida mística durante este mesmo período.

É uma destas ironias da história que exatamente seja São Bernardo de Claraval (1090-1153), defensor do aspecto místico e teológico da Mística, que devesse ser relacionado com a fatídica reviravolta na direção da experiência na Espiritualidade. Em um texto que se tornou famoso e que abre o terceiro sermão sobre o Cântico dos Cânticos, Bernardo escreveu: "Hoje o texto que nós devemos estudar será o livro da nossa própria experiência. De agora em diante vós deveis dirigir a vossa atenção para o interior onde cada um deve tomar nota da sua própria consciência particular das coisas que eu estou para falar".

Ainda em outros escritos, Bernardo insistirá sobre esta necessidade de uma experiência pessoal nos seus ouvintes como o único modo para entender a sua mensagem. É preciso entender de que modo Bernardo mesmo enten-

${ }^{33}$ C. MORRIS, The Discovery of the Individual. 1050-1200, New York: Harper \& Row, 1972, pp. 139-152. 
dia o que é a experiência: como bem observou Jean Leclerq, para uma figura monástica no tempo de Bernardo, "experiência" é essencialmente uma realidade comunitária, pessoal no sentido que é uma apropriação pessoal e existencial encarnação de uma comunidade que floresce em meio deste fervor comum. É uma experiência fundamentalmente bíblica e litúrgica nas suas fontes e pressupõe um processo de vida espiritual levado adiante por uma comunidade onde a finalidade essencial é a busca de Deus ${ }^{34}$.

Portanto, quando Bernardo fala de "experiência", ele não está falando de estados interiores, sentimentos ou somente da interioridade da pessoa, mas quer muito mais indicar a forma particular de presença de Deus na vida e na consciência de uma pessoa: a experiência de desejo ardente por Deus é a transcrição do desejo anterior de Deus pela alma: "é o resultado da alma que é já antes procurada e visitada" ${ }^{\prime 35}$. Todo indivíduo precisa ter a sua própria experiência da realidade, mas estas experiências não isolam a pessoa dos demais, mas a põem em relação a todos na comum aventura de buscar uma relação mais profunda com Deus.

Bernardo no seu Sermão sobre o Cântico dos Cânticos afirma que esta experiência é como uma melodia "que não escutarás pelas ruas... mas só a escutará aquele que a canta e aquele para quem ele a canta: o amante e o amado" (1, I.7).

Pode-se advertir aqui o explícito caráter privado, "não público", sugerido pelo texto. Não estamos nos movendo então, ao menos no plano do imaginário, de um âmbito público da história da salvação a um âmbito privado das emoções?

É certo que as dimensões afetivas da experiência se tornam especialmente significativas. De fato, Bernardo propõe também que os sentimentos são indicativos importantes da vida espiritual de uma pessoa. Os seus leitores são chamados a avaliar a estrutura emotiva das suas experiências e a partir destas análises concluir sobre a qualidade da relação individual deles com Deus.

Bernardo, com tais observações, queria somente dirigir os seus leitores para uma consciência mais aguda da fonte divina das experiências afetivas. Mas os guias espirituais posteriores tenderão quase exclusivamente a identificar as experiências mesmas como sendo o objeto principal da vida espiritual, sem referi-las à fonte divina delas.

${ }^{34}$ Cf. J. LECLERQ, Love of Learning and Desire for God: A Study of Monastic Culture, New York: Fordham University Press, 1974, p. 256.

${ }^{35}$ Sermo Super Cantica 84, vol. 2, 304. 
Em Bernardo isso jamais ocorre. Ele procura sempre advertir os seus ouvintes que não devem ser possessivos com relação às próprias experiências espirituais nem centrar demasiado a atenção sobre elas: "Enquanto este estado de alegria permanece, tu não deves usá-lo como se possuísses o dom de Deus como por direito de herança, seguro na convicção que não poderias nunca vir a perdê-lo; se Deus subitamente retirasse a sua mão e negasse o seu presente, tu serias imerso na depressão e na infelicidade" (21, II,7).

Dennys Turner, na sua sugestiva monografia The Darkness of God: Negativity in Christian Mysticism, mostrou exatamente como este experimentalismo levou ao nascimento da nossa moderna concepção de "mística":

Experiência $\longrightarrow$ Experiência individual $\longrightarrow$ Sentimentos interiores

Caminho para Deus $\rightarrow$ Atenção à interioridade $\rightarrow$ Experiências de interioridade

Quanto mais completa se torna a análise psicológica desta experiência, menos transparente ela se faz à sua fonte divina. No Século XVI este processo se torna tão desenvolvido que os escritores místicos não mais autorizam as suas asserções baseando-se na Escritura ou nas autoridades tradicionais, mas apelando muito mais ao $\mathrm{Eu}$, à experiência particular de quem fala. O discurso místico é entendido como emergindo do lugar secreto do eu interior. A teologia mística passa a indicar tudo o que se refere à vida do místico. A sua própria personalidade e gênio espiritual são vistos como uma chave para poder entender os textos místicos: a mística é então entendida como um drama interior atuado pelos sentimentos refinados do místico sobre o palco do eu interior.

Michel de Certeau sugere que já no tempo de uma Teresa de Ávila (15151582), este drama da vida interior era um substitutivo necessário para um cosmos que "não é mais percebido como capaz de falar de Deus, mas que se tornou opaco [...], destacado do seu suposto interlocutor" ${ }^{\prime 36}$.

O eu interior se torna então o substituto para um discurso mais público de Deus. Para Santa Teresa, o Castelo Interior se torna o ambiente no qual o discurso divino ainda pode ser escutado, mas agora a linguagem do discurso é constituída pelos movimentos interiores da alma. O "místico", na cultura ocidental, torna-se um personagem marginal, cujas experiências interiores podem suscitar curiosidade em alguns, mas sem dúvida sem uma grande relevância para a séria tarefa de uma teologia acadêmica.

${ }^{36}$ The Mystic Fable, Vol. 1, The Sixteenth and Seventeenth Centuries, Chicago: University of Chicago Press, 1992, p. 178. 


\section{Amar e conhecer: duas operações distintas ou inerentes uma à outra?}

Um outro modo de ler a história da separação entre teologia e espiritualidade seria considerar esta separação em termos do crescente divórcio que se dá na Idade Média entre Amor e Conhecimento. Para alguns de nós pode ser difícil entender o sentido de se falar de uma "mística intelectual", uma vez que fomos condicionados a pensar sempre o místico como sendo um jogo de sentimentos interiores de uma pessoa, a tal ponto que o papel do intelecto parece obscuro.

No Cristianismo primitivo, o processo da "noesis" ou conhecimento era sempre concebido em um modo intuitivo, associado sempre à intimidade, com o desejo que ocorre entre o conhecedor e o conhecido. Estamos muito distantes aqui da concepção moderna de uma análise científica de objetos manipuláveis da parte daquele que conhece. De fato, para S. Paulo é claro que a forma mais plena de conhecimento não pode ser um ato nosso, mas é certamente um evento em que a precedência cabe a Deus mesmo. Deus não é jamais um objeto conhecido, mas é Ele o Conhecedor de todo o processo (cf. 1Cor 13,12).

Partindo desta concepção, não é de se estranhar que a Tradição, passando por Agostinho (354-450) e S. Gregório Magno (c. 540-604), tenha sempre sublinhado que o amor e o conhecimento nos seus graus mais elevados são sempre considerados como profundamente inerentes um ao outro: "A alma deseja conhecer Deus porque o ama, e o ama porque ela conhece que Ele é a suprema Verdade e Beleza. Amor e conhecimento de Deus estão unidos neste tipo de conhecimento que nós temos de Deus, chamado de 'Sabedoria'"'37.

S. Gregório Magno: "O Amor em si mesmo é uma forma de conhecimento" (amore ipse notitia est) ${ }^{38}$.

Para S. Tomás de Aquino, o intelecto é um processo de união entre aquele que conhece e aquilo que é conhecido. Assim como a vontade anseia pelo bom, assim o intelecto anseia pelo verdadeiro; e como o "Deus-verdadeiro" e o "Deus-bom" são idênticos, as formas mais elevadas de conhecer e de querer (amar) coincidem inteiramente. Para S. Tomás, a contemplação é um ato do intelecto o qual realiza o desejo da vontade por Deus. A perfeição do conhecimento e do amor se encontra na contemplação de Deus. Na contemplação mística, não é o místico quem conhece e ama, mas muito mais ele é amado e conhecido por Deus.

${ }^{37}$ A. LOUTH, "Bernard and Affective Mysticism", in: B. UBARD (org.), The Influence of Saint Bernard, Oxford: SLG Press, 1976, p. 3.

${ }^{38}$ Homilia in Evangelia 27, PL 76, 1207. 
Contudo, uma leitura da vida mística primariamente em termos de interioridade levou a uma ruptura desta unidade. Já no final da Idade Média se considerava que o conhecer era tarefa dos teólogos, enquanto que o amar era função dos místicos. Ao invés de conceber o conhecer e o amar como atividades inerentes em Deus, estes eram vistos como estranhos um ao outro, como rivais e até mesmo inimigos, que lutavam para apoderar-se do drama interior do eu.

O impacto desta mudança sobre a relação entre Teologia mística e Teologia acadêmica não é difícil de se imaginar: Simon Tugwell fez notar que nos séculos XIII e XIV o próprio conceito de oração mudou de direção, passando a significar um desejo afetivo por Deus: "quanto mais a ênfase cai sobre alguns sentimentos como sendo cruciais na oração, mais a oração mesma se torna um perseguir conscientemente de tais sentimentos ${ }^{\prime \prime 39}$. Nesta situação se entende como a matriz comunitária, bíblica e litúrgica é abandonada, e passa a predominar uma preocupação pelos estados interiores do eu.

A linguagem metafísica da interioridade e do êxtase - que indicava a transcendência de toda experiência - é agora lida literalmente como uma busca de experimentar sentimentos interiores.

\section{À guisa de conclusão}

Uma teologia enraizada na espiritualidade seria uma teologia que cresce organicamente a partir do seu conhecimento próprio de Deus e fala sobre Deus mesmo. Portanto, se é verdade que a teologia exerce uma função indispensavelmente crítica para a espiritualidade, dando-lhe uma fundamentação sólida e critérios seguros para poder interpretar a sua experiência, não é menos verdade que também a espiritualidade se permite exercer ela também uma função radicalmente crítica com respeito à teologia, igualmente necessária para a saúde desta teologia.

Em outras palavras, a espiritualidade mantém a teologia na sua vocação própria, impedindo-a de fugir do seu objeto específico. A Espiritualidade não quer como a Teologia responder à pergunta "Quem é Deus", mas muito mais quer preservar uma orientação, uma perspectiva na qual esta pergunta possa permanecer sempre uma pergunta em aberto, sempre presente. A Espiritualidade situa a Teologia no Mistério da Morte e Ressurreição de Jesus, o qual é a Revelação de Deus mesmo e, portanto, a matriz de toda reflexão teológica honesta.

Como declara Louis Bouyer no seu livro "Mysterion": "O Mistério de Cristo, irredutível a nenhum outro, é o verdadeiro objeto da única mística à qual convenha o nome de mística cristã" ${ }^{\prime 40}$.

${ }^{39}$ S. TUGWELL, Ways of Imperfection: An Exploration of Christian Spirituality, London: Darton, Longman and Todd, 1984, pp. 116-117.

${ }^{40}$ L. BOUYER, Du mystère à la mystique, Paris: Oeil, 1986, p. 10. 
Cabe à Espiritualidade dar à Teologia este sentido do concreto espiritual, onde o desejo de conhecer vai unido à adesão do coração de penetrar e encontrar-se com o Mistério. O místico experimenta, com maior facilidade que o teólogo, a riqueza vital da realidade que ele experimenta ${ }^{41}$. A vida mística não se reduz a um tipo de conhecimento puramente intelectual, mas engloba sempre uma instância afetiva. Portanto, se a Teologia pretende tocar o Mistério que deseja penetrar deverá fazer-se também teologia afetiva, simbólica, "mística" no senso pleno da palavra.

Mostrando a unidade entre conhecimento e amor, impostando o vértice da vida espiritual na união transformante com o Senhor, os autores místicos reivindicam ter algo muito importante a dizer aos teólogos na sua missão de tornar mais inteligível a fé.

A função crítica da espiritualidade com respeito à teologia implica portanto o expor a teologia a este interrogatório profundo que anima o coração da comunidade na sua luta para permanecer fiel. Sem isso a teologia se arriscaria a perder o contato com o Deus verdadeiro que lhe deu vida, pois ninguém pode crer em um Deus pessoal com o qual não existe nenhuma interação ou comunicação!

Alfredo Sampaio Costa, SJ, é mestre (1997) e doutor (2001) em teologia pela Pontifícia Universidade Gregoriana (Roma), onde atualmente é professor adjunto de Teologia Espiritual Sistemática e de Espiritualidade. Além de artigos, publicou Los tiempos de elección en los Directorios de Ejercicios, Santander / Bilbao: Mensajero / Sal Terrae, 2004 (= Col. Manresa, 32).

Endereço: Pontificia Università Gregoriana

Piazza della Pilotta 04

00187 Roma - Itália

e-mail: sainlo@hotmail.it

${ }^{41}$ Cf. CH. A. BERNARD, Teologia mistica. Cinisello Balsamo (MI): San Paolo, 2006, p. 37. 